\title{
Pengaruh Jenis Zat Pengatur Tumbuh Terhadap Perkecambahan Benih Cendana (Santalum album Linn.)
}

\section{The Influence of The Several Types Plant Growth Regulator on Germination Sandalwood Seeds (Santalum Album Linn.)}

\author{
Viktorius Un ${ }^{1}$, Siti Farida ${ }^{2}$, Sama' Iradat Tito ${ }^{3}$ \\ 1 Jurusan Konservasi Sumberdaya Hutan, Fakultas Kehutanan, Institut Pertanian Malang \\ 2 Jurusan Teknologi Industri Pertanian, Fakultas Teknologi pertanian, Institut Pertanian Malang \\ ${ }^{3}$ Jurusan Konservasi Sumberdaya Hutan, Fakultas Kehutanan, Institut Pertanian Malang
}

\begin{abstract}
Abstrak
Salah satu permasalahan dalam perbanyakan tanaman cendana secara generatif yaitu perkecambahan biji yang lambat (dormansi), sehingga diperlukan upaya untuk mempercepat perkecambahan dengan pemberian Zat Pengatur Tumbuh (ZPT). Tujuan penelitian ini untuk mengetahui pengaruh jenis ZPT terhadap perkecambahan benih cendana. Penelitian dilakukan di Laboratorium Institut Pertanian Malang, mulai bulan Oktober sampai Desember 2017, menggunakan metode eksperimen. Rancangan yang digunakan ialah acak lengkap (RAL) dengan 5 perlakuan yaitu ; Kontrol menggunakan air tanah, air kelapa muda konsentrasi $70 \%$, simplisia kecambah kacang hijau konsentrasi $70 \%$, simplisia tomat konsentrasi $70 \%$ dan asam giberelat (GA3) konsentrasi 70\%. Pengamatam perkecambahan benih cendana meliputi Kecepatan berkecambah, daya kecambah, panjang plumula dan berat basah benih cendana. Data yang diperoleh dianalisis menggunakan analisis ragam pada taraf kepercayaan 95\% menggunakan Program SPSS statistics 24.0. Hasil penelitian menunjukkan bahwa penggunaan jenis ZPT terhadap perkecambahan benih cendana berpengaruh nyata terhadap semua parameter. Penggunaan ZPT GA3 menghasilkan pertumbuhan terbaik pada parameter kecepatan berkecambah dan berat basah dan berbeda nyata dengan perlakuan yang lain. Pada parameter panjang plumula, penggunaan GA3 tidak berbeda nyata dengan penggunaan air kelapa muda. Sedangkan untuk parameter daya kecambah, penggunaan GA3 tidak berbeda nyata dengan penggunaan air kelapa muda dan penggunaan simplisia tomat. Perlakuan yang menghaslikan rata-rata terendah adalah penggunaan air tanah (kontrol).
\end{abstract}

Kata kunci: Benih Cendana, GA3, Jenis Zat Pengatur Tumbuh

\begin{abstract}
Problems in the propagation of sandalwood plants are generative germination is slow because the seeds have dormancy, so it takes effort to accelerate germination with the provision of Plant Growth Regulator (ZPT). The purpose of this study was to determine the effect of several type of plant growth regulator on germination sandalwood seeds. The study was conducted at the Central Laboratory of the Malang Institute of Agriculture (IPM) from October to December 2017, using experimental methods. The design used was complete randomized (RAL) with 5 treatments, namely: Control using ground water, $70 \%$ coconut water concentration, simplicia of green bean sprouts concentration $70 \%$, simplicia of tomato concentration $70 \%$ and giberelin acid (GA3) concentration $70 \%$. The germination monitoring of sandalwood seeds include germination rate, germination, plumula length and wet sandalwood weight. The data obtained were analyzed using variance analysis at $95 \%$ confidence level with the SPSS statistics 24.0 program. The results showed that the use of several plant growth regulator substances to germination of sandalwood seeds significantly affected the germination rate, germination, plumula length and wet sandalwood seed weight. The use of GA3 plant growth regulator resulted in the best growth in germination rate parameters and the wet weight and significantly different from other treatments. In the plumula length parameter, GA3 usage having not significantly different with young coconut water treatment. While for germination parameter, GA3 usage not significantly different with young coconut water usage and tomato simplicia. The treatment of the lowest average is ground water usage (control).
\end{abstract}

Keywords: GA3, Sandalwood Seed, Several types of plant growth regulator

Correspondence address:

Viktorius un

Email : victorun7@gmail.com

Alamat : Jl. Alupan, RT/W: 001/001-Dusun Balibo - Desa As Manulea - Kecamatan Sasitamean - Kabupaten Malaka - Nusa Tenggara Timur 


\section{PENDAHULUAN}

Cendana (Santalum album Linn.) merupakan salah satu jenis dalam genus santalum yang tumbuh secara alami hanya di Indonesia [1]. Berdasarkan International Union for Conservation of Natural Resource (IUCN), tanaman cendana jenis Santalum album Linn. dimasukkan kedalam kategori jenis yang hampir punah (vulnerable) artinya cendana beresiko punah di alam liar dan akan punah jika waktu mendatang tidak segera ditangani. Sedangkan menurut CITES (Convention on International Trade in Endangered Species of Wild Fauna and Flora) cendana dimasukkan ke dalam jenis Appendix II yaitu daftar spesies yang tidak terancam kepunahan, tetapi akan terancam punah apabila perdagangan terus berlanjut tanpa adanya pengaturan [2] sehingga diperlukan upaya perbanyakan tanaman cendana baik melalui perbanyakan secara vegetatif maupun generatif.

Salah satu permasalahan dalam perbanyakan tanaman cendana secara generatif yaitu perkecambahan biji yang lambat karena biji mengalami dormansi sehingga diperlukan upaya untuk mempercepat perkecambahan dengan pemberian zat pengatur tumbuh (ZPT) untuk mengatur pertumbuhan dan perkembangan cendana.

Air kelapa, simplisia tauge, simplisia tomat dan asam giberelat (GA3) merupakan beberapa sumber hormon tumbuh (auksin, sitokinin dan giberelin) yang berperan dalam memacu pembelahan sel dan merangsang pertumbuhan sel $[3,4,5]$.

Penggunaan beberapa hormon diatas untuk mempercepat perkecambahan biji cendana belum pernah dilakukan, sehingga perlu penelitian tentang pengaruh jenis zat pengatur tumbuh terhadap perkecambahan biji cendana. Tujuan penelitian ini untuk mengetahui pengaruh jenis zat pengatur tumbuh terhadap perkecambahan benih cendana.

\section{METODE PENELITIAN}

Penelitian dilakukan di Laboratorium Pusat Institut Pertanian Malang (IPM) mulai bulan Oktober sampai Desember 2017. Penelitian ini menggunakan metode eksperimen. Rancangan yang digunakan ialah acak lengkap (RAL) dengan 5 perlakuan yaitu; Kontrol menggunakan air tanah (P0), air kelapa muda konsentrasi 70\% (P1), simplisia kecambah kacang hijau konsentrasi $70 \%$ (P2), simplisia tomat konsentrasi 70\% (P3) dan asam giberelat (GA3) konsentrasi $70 \%$ (P4), sehingga diperoleh 25 satuan percobaan. Pelaksanaan Kegiatan penelitian ini meliputi:

\section{a. Persiapan benih cendana}

Biji cendana yang digunakan berasal dari pohon induk asal Desa Kalatun Kabupaten Malaka. Benih yang dipilih bebas luka atau tidak cacat, kurang lebih mempunyai berat dan ukuran yang sama.

Biji kemudian direndam selama 12 jam di dalam larutan sesuai perlakuan. Apabila biji yang direndam tidak tenggelam atau mengapung maka biji tersebut dibuang dan diganti dengan biji lain yang bisa tenggelam.

\section{b. Persiapan larutan}

Larutan yang digunakan sesuai perlakuan yaitu Kontrol menggunakan air tanah (PO), air kelapa muda konsentrasi 70\% (P1), simplisia kecambah kacang hijau konsentrasi 70\% (P2), simplisia tomat konsentrasi $70 \%$ (P3) dan asam giberelat (GA3) konsentrasi $70 \%$ (P4). Langkah pembutan simplisia kecambah kacang hijau dan simplisia tomat dilakukan dengan menyiapkan $1 / 2 \mathrm{Kg}$ kecambah kacang hijau dan $1 / 4$ buah tomat kemudian diblender menggunakan blender lalu disaring menggunakan penyaring secara terpisah dengan masing-masing konsetrasi $70 \%$ dan ditambahkan dengan aquades $30 \%$.

\section{c. Perlakuan perendaman dan penaburan biji}

Perendaman biji cendana sesuai perlakuan selam 12 jam dengan tiap perlakuan diulang sebanyak 5 kali. Biji yang sudah direndam diangkat dan dikecambahkan dalam bak tabur yang sudah diisi dengan pasir steril.

\section{d. Pemeliharaan}

Kegiatan pemeliharaan yang dilakukan yaitu penyiraman dengan interval waktu 2-3 hari (disesuaikan dengan kondisi kelembaban media menggunakan volume air yang sama untuk masing-masing bak tabur). Parameter yang diamati antara lain:

\section{Kecepatan Berkecambah (\%/etmal)}

Pengamatan kecepatan berkecambah benih cendana dilakukan dengan interval waktu setiap 10 hari sekali. Rumus yang digunakan dalam menghitung kecepatan berkecambah[6] yaitu:

$\mathrm{Kct}=\frac{\% \mathrm{TN} 10}{\text { etmal } 10}+\frac{\% \mathrm{TN} 20}{\text { etmal } 20}+\ldots \frac{\% \mathrm{TN} 60}{\text { etmal } 60}$

Keterangan:

$\mathrm{Kct}=$ kecepatan berkecambah

\%TN=persentaseperkecambahan

Etmal=Interfal waktu pengamatan 


\section{Daya berkecambah (\%)}

Daya berkecambah ditunjukan dengan jumlah kecambah normal yang dapat dihasilkan oleh benih murni pada kondisi lingkungan tertentu dalam jangka waktu 30 hari.

Rumus untuk menghitung daya kecambah [6]:

$$
\mathrm{DB}=\frac{\text { Jumlah kecambah normal }}{\text { Jumlah benih yang diuji }} \times 100 \%
$$

\section{Tinggi Plumula Kecambah (cm)}

Pengukuran tinggi plumula kecambah dilakukan menggunakan penggaris dengan cara mengukur plumula kecambah dari pangkal batang (permukaan tanah) sampai titik tumbuh. Parameter tinggi plumula diukur pada akhir pengamatan.

\section{Berat Basah Kecambah (g)}

Pengamatan berat basah kecambah dilakukan pada hari ke 60 (akhir penelitian) dengan cara mengambil seluruh bagian kecambah sampel yang telah dibersihkan dari pasir yang menempel, dikering anginkan, kemudian menimbang berat basah kecambah dengan mengunakan timbangan analitik.

Data yang diperoleh dianalisis menggunakan analisis ragam pada taraf kepercayaan 95\%. Apabila hasil analisis ragam berpengaruh nyata dilanjutkan dengan uji BNT (Beda Nyata Terkecil) pada taraf $5 \%$ dengan Program SPSS statistics 24.0.

\section{HASIL DAN PEMBAHASAN}

\section{Kecepatan Berkecambah (\% etmal)}

Berdasarkan hasil analisis ragam diketahui bahwa jenis ZPT berpengaruh nyata terhadap kecepatan berkecambah benih cendana pada taraf uji 95\%. Rata-rata kecepatan berkecambah berkisar antara 2,6\%-5\%. Hasil uji BNT $\alpha$ : $5 \%$ diketahui bahwa perlakuan P0 sebesar 2,6\% dan P2 sebesar 2,8\% memiliki kecepatan berkecambah yang tidak berbeda nyata, kemudian perlakuan P3 memiliki kecepatan berkecambah sebesar $3,7 \%$ lebih tinggi dibandingkan perlakuan P2 dan PO.

Perlakuan P1 memiliki kecepatan berkecambah 4,5\% lebih tinggi dibandingkan perlakuan P0, P2, P3 tetapi lebih rendah dibandingkan perlakuan P4 yang menghasilkan kecepatan berkecambah tertinggi dibandingkan perlakuan lainnya. Tabel 1. menunjukkan rata-rata kecepatan berkecambah benih cendana pada perlakuan pengaruh penggunaan jenis ZPT.
Tabel 1. Rata-rata kecepatan berkecambah benih cendana pada berbagai perlakuan perendaman ZPT

\begin{tabular}{llll}
\hline No & \multicolumn{1}{c}{ Perlakuan } & $\begin{array}{l}\text { Rata- } \\
\text { rata }\end{array}$ & Keterangan \\
\hline 1 & P0 (Kontrol) & 2,6a & Angka yang \\
2 & P2 (Simplisia tauge) & 2,8a & diikuti huruf \\
3 & P3 (Simplisia tomat) & 3,7b & yang sama \\
4 & P1 (Air kelapa muda) & 4,5c & tidak berbeda \\
5 & P4 (GA3) & 5,0d & nyata \\
\hline
\end{tabular}

Sumber: Data terolah (2017)

Berdasarkan Tabel 1 diketahui bahwa perlakuan PO (kontrol menggunakan air tanah) menghasilkan persen kecepatan berkecambah yang tidak berbeda nyata dengan perlakuan P2 (simplisia tauge), tetapi lebih rendah dibandingkan dengan perlakuan yang lain. Hal ini diduga air tanah tidak mengandung ZPT alami yang cukup untuk mampu mempercepat pelunakan kulit benih cendana sehingga proses imbibisi lebih lambat.

Proses imbibisi pada benih berguna untuk meningkatkan kandungan air benih dan mengaktifkan enzim. Setelah terjadi penyerapan air, maka enzim diaktivir, kemudian masuk kedalam endosperm dan merombak zat cadangan makanan. Senyawa hasil perombakan tersebut larut dalam air dan dapat berdifusi [7].

Perlakuan P3 (simplisia tomat) menghasilkan kecepatan berkecambah lebih tinggi $(3,7 \%)$ dari pada perlakuan P2 dan P0. Hal ini diduga dalam simplisia tomat terdapat unsur hara, mineral, asam amino dan zat pengatur tumbuh bahan tanam (biji, akar jaringan tumbuh tanaman) yang dapat mendorong benih untuk berkecambah lebih cepat. Hal ini didukung oleh hasil penelitian[8] yang menemukan bahwa penggunaan ekstrak tomat memberikan respon terbaik pada pertumbuhan dan perkecambahan biji anggrek V.tricolor. sedangkan dalam penelitian [9], diperoleh hasil bahwa ekstrak tomat berpengaruh baik terhadap perkembangan dari embrio anggrek karena terdapat unsur hara, mineral, asam amino, zat pengatur tumbuh bahan tanam (biji, akar jaringan tumbuh tanaman) untuk tumbuh.

Perlakuan P1 memiliki kecepatan berkecambah 4,5\% lebih tinggi dibandingkan perlakuan P0, P2, P3 Hal ini diduga adanya ZPT yang terkandung dalam air kelapa muda seperti sitokinin, giberelin dan auksin dapat memacu pembelahan sel dan merangsang pertumbuhan tanaman. Hasil penelitian [5] diketahui air kelapa muda mengandung unsur hara dan ZPT sehingga dapat menstimulasi perkecambahan dan pertumbuhan biji tanaman. [10] Hormon auksin yang dikombinasikan dengan giberelin seperti 
yang terkandung dalam air kelapa dapat memacu pertumbuhan jaringan pembuluh dan mendorong pembelahan sel pada kambium pembuluh. Sitokinin dan giberelin yang terdapat dalam air kelapa muda berperan dalam merangsang perkecambahan benih biji palem putri secara nyata dengan konsentrasi air kelapa 75\% [11].

Penggunaan GA3 (P4) memberikan pengaruh nyata terhadap kecepatan berkecambah biji cendana dan menunjukkan hasil yang paling paling tinggi dibandingkan dengan P0, P1, P2 dan P3. Hal ini diduga kandungan hormon dan senyawa kimiawi yang dibuat secara sintetik memilik kemampuan yang lebih cepat untuk merangsang/mendorong serta mempercepat proses perkecambahan pada biji cendana. Pemberian zat pengatur tumbuh giberelin dapat meningkatkan perkecambahan biji meskipun dalam kondisi lingkungan yang kurang optimal [12] sehingga diperlukan hormon giberelin sebagai pendorong pertumbuhan tunas setelah proses imbibisi dan menyediakan cadangan makanan yang diperlukan untuk pertumbuhan embrio dalam perkecambahan biji [13].

Perbandingan rata-rata kecepatan berkecambah pada perlakuan perendaman dengan jenis ZPT dapat dilihat pada Gambar 1.

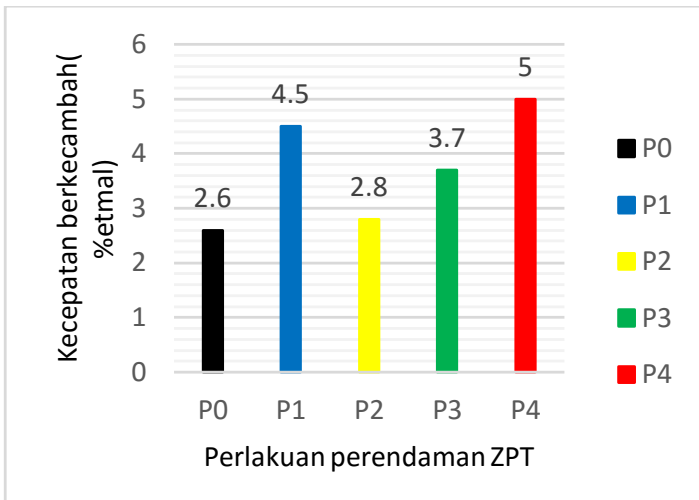

Gambar 1. Diagram rata-rata kecepatan berkecambah Sumber: Data terolah (2017)

\section{Daya Kecambah (\%)}

Berdasarkan hasil analisis ragam diketahui bahwa jenis ZPT berpengaruh nyata terhadap daya kecambah benih cendana pada taraf uji $95 \%$. Rata-rata daya kecambah berkisar antara 16\%$100 \%$. Hasil uji BNT $\alpha=5 \%$ diketahui bahwa perlakuan PO memiliki daya kecambah terendah yaitu sebesar $16 \%$ dan P2 sebesar $56 \%$, kemudian perlakuan P1, P3 dan P4 tidak terdapat perbedaaan yang nyata. Rata-rata presentase daya kecambah benih cendana tertera Tabel 2 .
Tabel 2. Rata-rata presentase daya kecambah (\%) pada berbagai perlakuan perendaman ZPT

\begin{tabular}{clcl}
\hline No & \multicolumn{1}{c}{ Perlakuan } & $\begin{array}{c}\text { Rata- } \\
\text { rata\% }\end{array}$ & Keterangan \\
\hline 1 & P0 (Kontrol) & $16 \mathrm{a}$ & Angka yang \\
2 & P2 (Simplisia tauge) & $56 \mathrm{~b}$ & diikuti huruf \\
3 & P3 (Simplisia tomat) & $88 \mathrm{c}$ & yang sama \\
4 & P1 (Air kelapa muda) & $96 \mathrm{c}$ & tidak berbeda \\
5 & P4 (GA3) & $100 \mathrm{c}$ & nyata \\
\hline
\end{tabular}

Sumber: Data terolah (2017

Berdasarkan Tabel 2 diketahui bahwa perlakuan PO (kontrol menggunakan air tanah) menghasilkan persentase daya kecambah paling rendah sebesar $16 \%$. Hal ini karena air tanah belum mampu memecah dormansi dan melunakkan kulit benih cendana sehingga proses imbibisi lebih lambat. Bila proses imbibisi lambat maka alfa amylase kurang terbentuk karena terhalangnya proses perombakan pati (amylase dan amilopektin) yang dapat mengakibatkan lambatnya perkecambahan [14].

Perlakuan P2 (simplisia tauge) menghasilkan presentase rata-rata daya kecambah sebesar $56 \%$ lebih tinggi dibandingkan perlakuan PO. Hal ini diduga kecambah tauge kacang hijau mengandung giberelin yang digunakan untuk menggiatkan enzim hidrolitik, sitokinin untuk merangsang pembelahan sel dan auksin untuk meningkatkan pertumbuhan dan perbesaran sel [15].

Pada perlakuan P4 (GA3), P3 (simplisia tomat) dan P1 (air kelapa muda), menghasilkan rata-rata presentase daya kecambah biji cendana yang tidak berbeda nyata yaitu berkisar antara $88 \%$ $100 \%$, tetapi lebih tinggi dari perlakuan P2 dan P0. Hal ini diduga air kelapa muda (P1), simplisia tomat (P3) dan GA3 (P4) terdapat kandungan hormon giberelin, sitokinin dan auksin. Adanya kandungan ZPT dalam ketiga perlakuan tersebut akan mempercepat permeabilitas masuknya air kedalam sel, mempertinggi penyerapan diantaranya unsur $\mathrm{N}, \mathrm{Mg}, \mathrm{Fe}, \mathrm{Cu}$ serta dapat menaikkan tekanan osmotik menyebabkan pengurangan tekanan pada dinding sel, meningkatkan sintesis protein, meningkatkan plastisitas dan pengembangan dinding sel.

Asam giberelin didifusikan ke lapisan aleuron, yang merupakan tempat pembuatan enzim-enzim hidrolitik (alfa amilase, protease, beta gluconase, fosfatase). Enzim-enzim hidrolitik kemudian berdifusi ke endosperm menjadi gula dan asamasam amino yang berperan membantu pertumbuhan dari embrio biji tersebut [16]. Giberelin juga meningkatkan enzim proteinase yang mengubah protein menjadi asam amino dan 
enzim lipase yang mengubah lemak menjadi asam lemak dan gliserol yang larut [17]. Perubahan cadangan makanan menjadi zat-zat menyebabkan pengangkutan merata keseluruh bagian embrio sehingga benih dapat berkecambah. Kandungan hormon giberelin berpengaruh terhadap perkembangan dan perkecambahan embrio [18]. Selain itu giberelin dapat merangsang pembentukan enzim amylase yang berperan memecah senyawa amilum pada endosperm (cadangan makanan) menjadi senyawa glukosa. Glukosa ini menjadi sumber energi untuk proses perkecambahan dan pertumbuhan cendana secara menyeluruh. Rata-rata persentase daya kecambah tersaji pada Gambar 2.

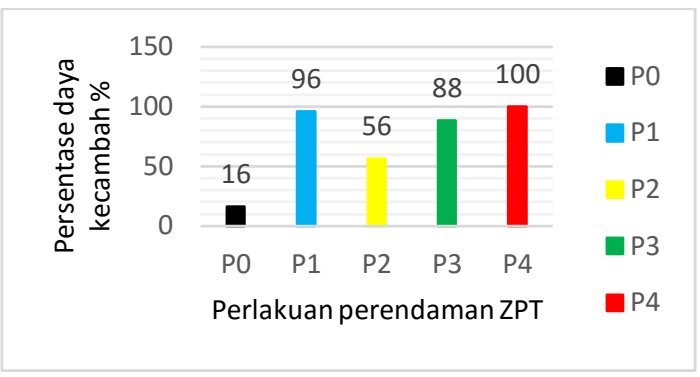

Gambar 2. Diagram Rata-rata daya kecambah Sumber: Data terolah (2017)

\section{Panjang Plumula (cm)}

Berdasarkan hasil analisis ragam diketahui bahwa jenis ZPT berpengaruh nyata terhadap panjang plumula biji cendana pada taraf uji $95 \%$. Rata-rata panjang plumula berkisar antara $24 \mathrm{~cm}$ $55 \mathrm{~cm}$. Hasil uji BNT $\alpha=5 \%$, diketahui bahwa perlakuan PO memiliki rata-rata panjang plumula terendah yaitu sebesar $24,36 \mathrm{~cm}$, kemudian perlakuan $\mathrm{P} 2$ sebesar $42,74 \mathrm{~cm}$, perlakuan P3 sebesar $47,06 \mathrm{~cm}$. Selanjutnya perlakuan P1 sebesar $52,82 \mathrm{~cm}$ dan perlakuan $\mathrm{P} 4$ sebesar 55,34 $\mathrm{cm}$. Perlakuan P1 dan P4 berbeda tidak nyata namun perlakuan P4 cendrung lebih tinggi dibandingkan dengan perlakuan P1 pada panjang plumula kecambah cendana. Tabel 3 berikut menunjukkan rata-rata panjang plumula cendana pada perlakuan pengaruh penggunaan jenis ZPT.

Tabel 3. Rata-rata pengaruh penggunaan jenis ZPT terhadap panjang plumula pada uji BNT 5\%

\begin{tabular}{clcl}
\hline No & \multicolumn{1}{c}{ Perlakuan } & $\begin{array}{c}\text { Rata-rata } \\
\text { (cm) }\end{array}$ & Keterangan \\
\hline 1 & P0 (Kontrol) & $24.36 \mathrm{a}$ & Angka yang \\
2 & P2 (Simplisia tauge) & $42.74 \mathrm{~b}$ & diikuti huruf \\
3 & P3 (Simplisia tomat) & $47.06 \mathrm{c}$ & yang sama \\
4 & P1 (Air kelapa muda) & $52,82 \mathrm{~d}$ & tidak berbed \\
5 & P4 (GA3) & $55,34 \mathrm{~d}$ & a nyata \\
\hline
\end{tabular}

Sumber: Data terolah (2017
Berdasarkan Tabel 3. diketahui bahwa perlakuan PO (kontrol menggunakan air tanah) menghasilkan panjang plumula terendah. Hal ini diduga air tanah tidak mengandung unsur hara yang dibutuhkan oleh tanaman cendana untuk proses pertumbuhan dan perkembangan sel tanaman. Kemudian perlakuan P2 menghasilkan panjang plumula yang lebih tinggi dibandingkan perlakuan PO.

Perlakuan P3 memiliki rata-rata panjang plumula yang lebih tinggi dari pada perlakuan P2 dan PO. Hal ini diduga adanya kandungan hormon giberelin, sitokinin dan auksin dalam simplisia tomat (P3) yang secara sinergis berperan memacu pertumbuhan tanaman cendana baik pertumbuhan akar maupun pertumbuhan batang.

Perlakuan P4 berpengaruh secara signifikan terhadap panjang plumula cendana dan tidak berbeda nyata dengan perlakuan $\mathrm{P} 1$, tetapi perlakuan $\mathrm{P} 4$ cendrung memiliki rata-rata panjang plumula lebih tinggi dari $\mathrm{P} 1$, hal ini diduga karena hormon giberelin yang terkandung dalam air kelapa lebih sedikit dibandingkan dengan GA3 yang berperan memacu perpanjangan batang serta pertumbuhan seluruh bagian tumbuhan dan merangsang sintesis auksin yang sangat dibutuhkan untuk pertumbuhan tanaman [5]. Pemberian giberelin dapat meningkatkan pertambahan tinggi tanaman dan merangsang pemanjangan batang serta pembelahan sel. Peningkatan giberelin pada suatu tanaman selalu diiringi oleh peningkatan auksin dan sitokinin dan bersinergi membantu meningkatkan pertumbuhan dan perkembangan tanaman [19]. Penggunaan air kelapa mampu meningkatkan pertumbuhan bibit stek lada secara nyata pada panjang batang. Keadaan ini mengindikasikan bahwa kandungan hormon auksin, sitokinin dan giberilin dalam air kelapa dapat memacu dan meningkatkan benih cendana [20]. Peran zat pengatur tumbuh sitokinin, auksin dan giberelin bersinergi meningkatkan pertambahan panjang plumula kecambah cendana. Pengaruh jenis ZPT terhadap panjang plumula kecambah cendana tersaji pada Gambar 3.

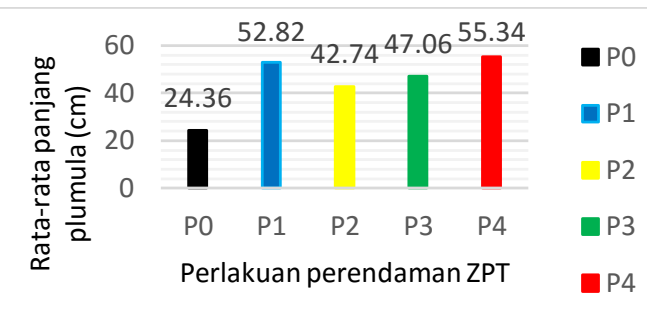

Gambar 3. Diagram rata-rata panjang plumula $(\mathrm{cm})$ 
Sumber: Data terolah (2017)

\section{Berat Basah}

Berdasarkan hasil analisis ragam diketahui bahwa jenis ZPT berpengaruh nyata terhadap berat basah cendana pada taraf uji 95\%. Rata-rata berat basah berkisar antara 0,66 g - 1,61 g. Hasil uji BNT $\alpha=5 \%$ diketahui bahwa perlakuan PO memiliki berat basah terendah yaitu sebesar 0,66 g, perlakuan P2 sebesar 50,82 g kemudian perlakuan P3 sebesar $0,96 \mathrm{~g}$, perlakuan $\mathrm{P} 1$ sebesar $1,27 \mathrm{~g}$, dan perlakuan P4 memiliki persen berat basah tertinggi yaitu 1,61 g. Rata-rata berat basah kecambah cendana pada perlakuan pengaruh penggunaan jenis ZPT tersaji pada Tabel 4.

Tabel 4. Rata-rata pengaruh penggunaan jenis ZPT terhadap berat basah kecambah cendana $(\mathrm{g})$

\begin{tabular}{clcl}
\hline No & \multicolumn{1}{c}{ Perlakuan } & $\begin{array}{c}\text { Rata-rata } \\
\text { (g) }\end{array}$ & Keterangan \\
\hline 1 & P0 (Kontrol) & $0,66 \mathrm{a}$ & Angka yang \\
2 & P2 (Simplisia tauge) & $0,82 \mathrm{~b}$ & diikuti huruf \\
3 & P3 (Simplisia tomat) & $0,96 \mathrm{c}$ & yang sama \\
4 & P1 (Air kelapa muda) & $1,27 \mathrm{~d}$ & tidak berbed \\
5 & P4 (GA3) & $1,61 \mathrm{e}$ & a nyata \\
\hline Sumber: Data terolah (2017 & &
\end{tabular}

Berdasarkan Tabel 4 diketahui bahwa perlakuan PO (kontrol menggunakan air tanah) menghasilkan persen berat basah terendah, hal ini diduga karena kurang atau tidak tersedianya kandungan zat hara dalam air tanah yang dibutuhkan tanaman cendana untuk proses pertumbuhan dan perkembangan, sedangkan pada perlakuan P2, P3, P1 dan P4 menghasilkan berat basah kecambah yang berbeda dari pada PO (Kontrol).

Perlakuan P3 berbeda nyata dengan perlakuan P2 dan perlakuan PO. Hal ini diduga pengaruh zat pengatur tumbuh dan senyawa kimiawi dalam simplisia tomat dapat memacu pertambahan berat basah kecambah cendana. Simplisia tomat menyediakan unsur hara, mineral, asam amino serta zat pengatur tumbuh bahan tanam (biji, akar jaringan tumbuh tanaman) untuk tumbuh sehingga dapat memacu berat basah tanaman [9]. Pada perlakuan P1 berbeda nyata dengan perlakuan P3, P2 dan P0. Hal ini diduga kandungan ZPT pada air kelapa memiliki kemampuan meningkatkan berat basah kecambah cendana yang didukung oleh penelitian yang menemukan bahwa [21] pemberian air kelapa $60 \%$ dapat meningkatkan berat basah tajuk 2,37 g.

Perlakuan $\mathrm{P} 4$ berbeda nyata dengan perlakuan P0, P1, P2, P3 dan merupakan perlakuan yang menghasilkan rata-rata berat basah tertinggi dari semua perlakuan. Hal ini diduga karena peran zat pengatur tumbuh GA3 mampu menjalankan perannya dengan optimal sehingga berpengaruh terhadap pembentukan berat basah. [22] Hormon giberelin merangsang pembentukan enzim amylase, maltase, dan pemecah protein sehingga terjadi pembelahan sel pada daerah meristem batang dan kambium, yang berakibat pada penambaha bobot berat basah tanaman. Perbedaan rata-rata berat basah kecambah cendana perlakuan perendaman jenis ZPT tertera pada Gambar 4.

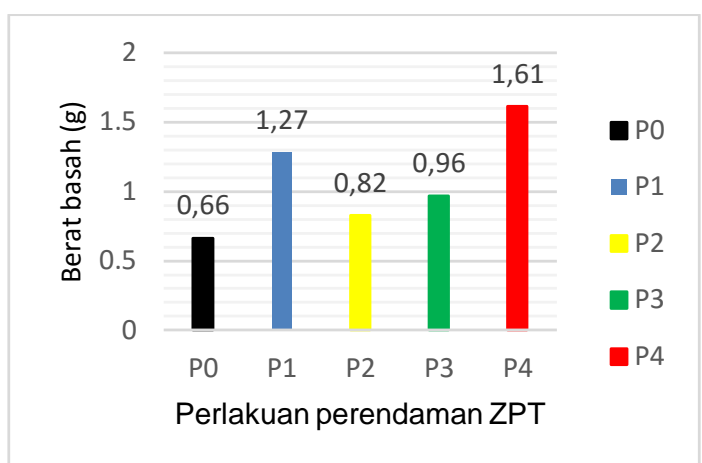

Gambar 4. Diagram rata-rata berat basah benih cendana Sumber: Data terolah (2017)

\section{KESIMPULAN}

Penggunaan jenis zat pengatur tumbuh (air kelapa muda (P1), simplisia tauge (P2), simplisia tomat (P3), dan GA3 (P4)) terhadap perkecambahan benih cendana berpengaruh secara signifikan terhadap parameter kecepatan berkecambah, daya kecambah, panjang plumula dan berat basah benih cendana. Penggunaan GA3 memiliki rata-rata tertinggi sedangkan penggunaan air tanah memeliki rata-rata paling rendah pada semua parameter.

Hasil penelitian menunjukkan bahwa penggunaan jenis zat pengatur terhadap perkecambahan benih cendana berpengaruh nyata terhadap parameter kecepatan berkecambah, daya kecambah, panjang plumula dan berat basah benih cendana. Penggunaan Zat pengatur tumbuh GA3 menghasilkan pertumbuhan terbaik pada parameter kecepatan berkecambah sebesar 5,0\% etmal dan berat basah sebesar 1,6 gram dan berbeda nyata dengan perlakuan yang lain.

Pada parameter panjang plumula, penggunaan GA3 menghasilkan rata-rata sebesar $55,34 \mathrm{~cm}$ dan tidak berbeda nyata dengan perlakuan air kelapa yang menghasilkan rata-rata sebesar $52,82 \mathrm{~cm}$. Sedangkan untuk parameter daya kecambah, penggunaan GA3 menghasilkan 
rata-rata sebesar $100 \%$, tidak berbeda nyata dengan penggunaan air kelapa muda (96\%) dan penggunaan simplisia tomat (86\%).

Perlakuan yang menghaslikan rata-rata terendah adalah penggunaan air tanah (kontrol) pada parameter daya kecambah, panjang plumula dan berat basah benih, sedangkan untuk parameter kecepatan berkecambah tidak berbeda nyata dengan penggunaan simplisia tauge.

\section{Saran}

1. Perlu adanya penelitian tentang penggunaan zat pengatur tumbuh yang alami maupun kimiawi untuk mempercepat pertumbuhan dan perkembangan benih cendana.

2. Perlu penelitian lanjutan untuk mengetahui pengaruh konsentrasi jenis zat pengatur tumbuh dengan menambahkan atau menggabungkan konsentrasi yang digunakan dalam penelitian ini.

\section{UCAPAN TERIMA KASIH}

Penulis menyampaikan terima kasih kepada orang tua tercinta (Maximus Nana dan Rosalinda Bubu), saudari Ordi, Vita, Winda Rina dan Vyna serta rekan-rekan seperjuangan yang telah membantu penulis dalam penyelesaian karya tulis ini.

Sadar akan kekurangan dan keterbatasan penulis, maka penulis sangat mengharapkan kritik dan saran yang ada relevansinya dan bersifat membangun demi kesempurnaan karya tulis ini.

\section{DAFTAR PUSTAKA}

[1]. Rahayu, S., Wawo, A. H., Van Noordwijk, M dan Harirah, K. 2002. Cendana, Deregulasi dan Strategi Pengembangannya. Word Agroforestry Centre-ICRAF, Bogor.

[2]. IUCN. (2013). IUCN Red List of Threatened Species. (Version 2013.2) dalam Prosiding Asian Regional Workshop (Conservation \& Sustainable Management of Trees, Viet Nam, August 1996. www.iucnredlist.org. Diakses tanggal 29 Maret 2017.

[3]. Djamhuri E. 2011. Pemanfaatan Air Kelapa Untuk Meningkatkan Pertumbuhan Setek Pucuk Meranti Tembaga (Shorea leprosula Miq.). Jurnal Silvikultur Tropika. 02(01): 5-8.

[4]. Dwiyani, R., A. Purwantoro, A. Indrianto dan E. Semiarti. 2009. Peningkatan Kecepatan Pertumbuhan Embrio Anggrek Vanda tricolor Lindl. Pada Medium Diperkaya dengan Ekstrak Tomat dalam Prosiding Seminar Nasional Biologi XX dan Kongres
Perhimpunan Biologi Indonesia XIV, 24 - 25 Juli 2009, hlm. $360-365$.

[5]. Bey, Y., Syafii, W. dan Sutrisna. 2006. Pengaruh Pemberian Giberelin (GA3) dan Air Kelapa terhadap Perkecambahan Bahan Biji Anggrek Bulan (Phalaenopsis Amabilis BI) secara In Vitro. Jurnal Biogenesis, 2(2). 4146.

[6]. Sutopo, L. 2002. Teknologi Benih. Fakultas Pertanian. Universitas Brawijaya. PT Raja Grafindo pesrsada, XVI, 238.

[7]. Harry, Mugnisyah dan Murniati. 1990. Biologi Benih. Departemen Pendidikan Tinggi. Pusat Antar Universitas Ilmu Hayat. Institut Pertanian Bogor. Bogor.

[8]. Dwiyani, Rindang. 2013. Perkecambahn Biji dan Pertumbuhan Protokorm Angrek Dari Buah Dengan Umur Yang Berbeda Pada Media Kultur Yang Diperkaya Dengan Ekstrak Tomat. J.Hort. Indonesia 4(2):90-93.

[9]. Gunawan, L. W. 1992. Teknik Kultur Jaringan Tanaman. Laboratorium Kultur Jaringan, Pusat Antar Universitas, IPB. Bogor.

[10]. Wattimena, G.A. 1987. Zat Pengatur Tumbuh Tanaman. Pusat Antar Universitas Bioteknologi IPB, Bogor.

[11]. Sujarwati, S., Fathonah, Johadi, E dan Herlina. 2010. Penggunaan Air Kelapa Untuk Meningkatkan Perkecambahan dan Pertumbuhan Palem Putri (Veitchia merllii), SAGU, 10(1). 24-28.

[12]. Sultana N, Ikeda T, Mitsui T. 2000. GA3 and proline promote germinatition of wheat seeds by stimulating $\alpha$-amylase at unfavorable temperatures. Pland prod. Sci., 3(3). 232-237.

[13]. Ashari, S. 1995. Holtikultura aspek budidaya, UI-Press. Jakarta.

[14]. Harry, S, P., Mugnisyah, W. Q., dan Murniati, E. 1990. Biologi Benih. Departemen Pendidikan Tinggi. Pusat Antar Universitas Ilmu Hayat. Institut Pertanian Bogor. Bogor.

[15]. Gardner, P. F. dan R.B. Pearce. 1991. Fisiologi Tanaman Budidaya. Universitas Indonesia Press. Jakarta.

[16]. Karmil, Jurnalis. 1979. Teknologi Benih 1. Padang: Angkasa Raya.

[17]. Wilkins MB. 1989. Fisiologi Tanaman Budidaya. Terjemahan Sutedjo, M dan A.G. Kartasapoetra. Jakarta: Gramedia.

[18]. Goldsorthy, P. R. dan Fisher, N. M. 1992. Fisiologi Tanaman Budidaya Tropik (Penerjemah: Tohari). Universitas Gadjah Mada Press.Yogyakarta. 
[19]. Salisbury, F. B and Ross, C. W. 1995. Fisiologi Tumbuhan. Jilid 3. (Penerjemah: Diah R, Lukman dan Sumaryono). Penerbit ITB. Bandung.

[20]. Aguzaen, H. 2009. Respon Pertumbuhan Bibit Stek Lada (Piper Nisrum L.) terhadap Pemberian Air Kelapa dan Berbagai Jenis CMA. Agronobis, 1 (1). 36-47.

[21]. Wulandari, R.C., Linda, R. \& Mukarlina (2013) Pertumbuhan Stek Melati Putih (Jasminum sambac (L) W.Ait.) dengan Pemberian Air Kelapa dan IBA (Indole Butyric Acid). Jurnal Protobiont. 2 (2). 39-42.

[22]. Kusumo S. 1984. Zat Pengatur Tumbuh Tanaman. Jakarta: Yasaguna. 